Original scientific article

UDC: 613.94:323.15(4)"1900/1944"

COBISS.SR-ID 219469836

\author{
Marius Turda \\ Oxford Brookes University \\ Headington Campus, Oxford OX3 0BP, UK \\ E-mail: mturda@brookes.ac.uk
}

\title{
MINORITIES AND EUGENIC SUBCULTURES IN EAST-CENTRAL EUROPE*
}

\begin{abstract}
This paper offers an overview of eugenic sub-cultures in EastCentral Europe developed between 1900 and 1944. Special attention has been paid to the intricate issue of ethnic survival and minority rights, along with the process of ideological transmission and application of eugenics within regional, national and trans-national contexts. The eugenic strategy pursued by ethnic minorities in EastCentral Europe was meant to ensure their survival amidst a growing trend towards national homogenisation and eradication regional differences. Importantly, these eugenic sub-cultures aimed not only to revive the ethnic minority from within but to reshape its relationship with the host nation-state, based upon principles of racial exclusivity, homogeneity and protectionism.
\end{abstract}

Keywords: eugenics

Non MeSH: sub-cultures, ethnic minorities, East-Central Europe, racial protectionism

In 1941 the Calvinist pastor of the village of Börvely (Rom: Berveni), a small village situated in northwestern Transylvania (Satu Mare county) wrote a letter to the Prime Minister of Hungary, Pál Teleki. This is the region that was returned to Hungary after the Second Vienna Award in August 1940, having been part of Romania since 1918.

The pastor pleaded with the Teleki that Szeklers from Bukovina be allowed to re-settle in his village. After Trianon, the pastor explained, this Hungarian village was cut off the national body. Preserving Hungarian traditions kept the community

\footnotetext{
* The research for this article was made possible by a British Government AHRC grant, as part of a wider project at the University of Oxford and Oxford Brookes University, 'Sub-Cultures as Integrative Forces in East-Central Europe, c. 1900-present' (2012-16). I am also grateful to the participants at the 'Hybrid Identity' workshop, Uniwersytet Pedagogyczny (Kraków, Poland, September 2014), particularly Drs Jan Fellerer and Robert Pyrah, for their feedback on my initial findings.
} 
alive, but surrounded by Swabians and Romanians the Hungarian villagers had to resort to endogamy, promoted as their unique strategy of racial survival. After twenty years, this isolationist marriage practice had however greatly affected the villagers' well being, both physical and moral; they, in other words, had become "degenerate." The transfers of population orchestrated by the Hungarian government at the time provided the pastor the solution for his village's biological deterioration. The resettlement of 100 families of Szeklers from Bukovina in Börvely, the priest believed, would reinforce the villagers' depleted racial vitality, providing the muchneeded population renewal.

This letter offers a rare insight into the struggle for ethnic survival of the Hungarian ethnic minority in northern Transylvania during the early 1940s. If in the mid-nineteenth century, the great Hungarian statesman István Széchenyi set the course of Hungarian nationalism by famously pronouncing that the 'nation lives in its language', by the mid-twenty century, his epigones in northern Transylvania recodified this statement to reflect the new historical realities. 'The nation', the pastor declared, 'lived in its race' [1].

Moreover, as this letter clearly demonstrates, during the Second World War, ethnic minorities as much as ethnic majorities engaged directly with eugenic strategies of national survival; yet these strategies remain poorly understood. There is a relentless tendency amongst scholars of East-Central Europe to concentrate mostly on the articulation of cultural and political identity. What is the role of history, memory, language, imagination and myth in the formation of ethnically multi-layered identity? This is certainly a very important question, one that both scholars of nationalism and nationalists themselves have struggled with for decades, but one that scholars of eugenics seem less attracted to. The life of the ethnic community itself, and everything that it entails in terms of marriage, reproduction, children, and so on, may simply be difficult to gauge from existing historical sources, but there is one conceptual strategy which could enable the researcher to approach both the question of identity and the eugenic project built on it. This methodology draws inspiration from Ernst Bloch's concept of the "simultaneity of non-simultaneous" ("die 'Ungleichzeitigket' des Gleichzeitigen"), which aims to explain multiple and synchronous temporalities [2]. Bloch believed that people live together at the same time but not in the same time, and this is a very apt description of the relationship between ethnic minorities and majorities in East-Central Europe during the interwar period.

National histories continue to downplay the importance of eugenics to politics and culture. One reason for this neglect is that most work on ethnic minorities and majorities emphasise the importance of language and culture, as effective strategies in preserving the identity of those communities. Such a scholarly enterprise is no doubt justified, yet I believe it to be often insufficient. In other words, whilst not denying the importance of language and culture, I argue that understanding the physical reality of the community - the individuals and families that constitute it is also central to an understanding of the relationship between ethnic minorities and dominant majorities in East-Central Europe [3]. Studies in recent years, fortunately, have countered the long-held view that eugenics had little bearing on the history 
of East-Central Europe. There is now a growing consensus, at least amongst social historians of medicine, that one's physical belonging to an ethnic community coexisted with, and cemented, other sources of identity such as religion, language, culture, or shared historical experiences. It was this fluid relationship between cultural expressions of identity and the biologisation of belonging that informed the formation of eugenic sub-cultures in East-Central Europe after 1900 [4].

I define sub-cultures as sites of multi-layered, simultaneous forms of identity, which develop underneath the locally dominant projects of cultural and identity politics, but are not in a subaltern position. Moreover, the identity project of the minority often developed simultaneously with that of the majority, albeit based on a different historical trajectory. In turn, eugenic sub-cultures in East-Central Europe that is to say those clusters of ideas, agendas and programmes devised to ensure the biological survival of the national community - are those forms of identity which emerged not only as critiques of certain processes of political, legal and institutional control over a given population contained within a delimited territorial space, but also as the expression of a distinctive biological) and social problems (for example, the decline in fertility or intermarriages). In many instances, eugenic sub-cultures reinforced the cultural and social boundaries that separated those who belonged to the national community from foreigners and outsiders who were often seen as potential enemies [5]. In addition to this defensive, external strategy of ethnic protectionism, another one developed, a system of 'internal cleansing', according to which those members of the community deemed "unhealthy," "diseased" and "antisocial" were subjected to various interventionist measures, both in their personal and public lives.

Eugenic subcultures in East-Central Europe are defined by three essential components, which I shall discuss briefly:

1. simultaneity

2. specific sub-cultural context

3. identity project

\section{Simultaneity}

Between 1900 and 1944, national communities (both minority and majority) in East-Central Europe engaged directly with the basic notion that the nation can and must be eugenically improved $[6,7]$. This proliferation of eugenic ideas and practices resulted in a number of welfare and family initiatives designated to control, govern and protect the ethnic community, at local, regional and national levels. These emerging eugenic sub-cultures were also defined by a new nationalist mentality connecting, family, fertility and reproduction with racial survival. Through economic incentives, the national community increased efforts to strengthen its social basis and economic prosperity; through measures to oppose birth control it planned demographic growth; finally, through eugenic screening and social medicine it hoped to create a healthy population. 
Some of the eugenic sub-cultures in countries such as Romania, Yugoslavia, Poland and Czechoslovakia existed largely in isolation. The Germans (Saxons) in Transylvania, for instance, adopted this strategy of separation as a way of preserving their ethnic identity and the transmission of narratives about the past. The German eugenic project paralleled the Hungarian and the Romanian ones but it rarely interacted with them. One example of how Hungarian eugenicists in Transylvania reacted to the Romanian eugenic movement is provided by Dénes László, a physician from Nagybánya (northern Transylvania), who contrasted Francis Galton's definition of eugenics, which - László commented - dealt only those aspects that influence the future generation, to that proposed by "a Romanian author: Professor Moldovan, who promotes the notion of national hygiene". Moldovan's definition of eugenics and of "the nation is a biological and racial formation" appealed to László [8].

To heighten the simultaneous nature of the German, Hungarian and Romanian eugenic movements, it is worth considering various eugenic strategies employed by the state, the Churches and local associations (charity; child welfare; social assistance) in Transylvania their plans and implementation. Another common feature was what I call 'eugenic pastoralism', namely the admiration of rural communities seen as vital to the racial health of the nation [9].

Eugenic sub-cultures belong to a whole series of interrelated clusters (biological, social, cultural, political, economic, religious and linguistic), which cannot be fully understood unless their own identity project is unveiled and explored. With respect to national communities in East-Central Europe, one component of this identity project deserved particular attention: the belief in national regeneration. Eugenics incorporated this craving for a new ideal of the national community to be achieved through a programme of social and biological improvement. Disclosed in this programme was a clear set of principles centred upon protecting the hereditary qualities of the national community, whilst simultaneously preventing it from miscegenation and assimilation.

\section{Sub-cultural not Subaltern}

Contrary to other scholarly traditions, eugenic sub-cultures do not operate within established dichotomies, such as East vs. West; centre vs. periphery; developed vs. backward, and so on. The method of identifying sub-cultural relations (where they indeed existed!) between minorities and majorities can be supplemented by describing different eugenic traditions as integrative forces. To identify a specific subcultural context (for example the city of Hermannstadt/Sibiu in Transylvania during the 1930s) is to understand the simultaneous application of eugenic theories by the state and its ethnic minorities and they coalesced around shared themes, the first of which was the rejection of assimilation whilst celebrating the idea of integration. The other theme was, of course, the demand for political equality, whilst demanding distinct cultural and linguistic recognition.

A discussion of eugenic sub-cultures in East-Central Europe in general and in Romania in particular embraces both universalism and particularism, at the 
interstices of which we can place the crucial theoretical problem of our research: the incompatibility between the myth of the nation-state (based on ambition to create a Romanian state) and the 'myth of Greater Romania' (based on the dream to create a super-state for all Romanians).

Aggravating these perceptions of racial decline, a plethora of 'socio-biological' studies on differential fertility warned that the community's most valuable individuals and families were slowly dying out. Such views were already put forward at the end of the nineteenth century. For instance, in 1885, Oskar von Meltzl published the highly influential Statistics of the Saxon Rural Population, in which he explained the declining number of Saxon settlements as the result of Hungarian and Romanian populations moving into areas already emptied of their Saxon inhabitants by wars, diseases, and emigration. The antidote provided to the growing loss of Saxon 'racial vitality' was based both on the reinforcement of Saxon ethnic particularity vis-à-vis other ethnic groups and on demands for racial renewal [10].

There were, of course, some significant differences too. In the Saxon case, one pragmatic concern was the decline in birth-rates, coupled with the fear of being outnumbered by Romanians and Hungarians. In language charged with racial idioms, Saxon eugenicists urged the members of their community to reproduce responsibly whilst putting pressure on institutions such as the church and the school to intervene to prevent the process of racial degeneration. To this effect, Saxon eugenicists publicly stressed the imperative for various welfare organisations to take an active role in the maintenance and improvement of its population's physical and mental qualities. Often they were at once hygienist and hereditarian in their outlook, emphasizing as much the improvement of the nation's social environment as its hereditary legacy.

Eugenics was gradually seen as an integral part of a wider programme of social, cultural and political reform, and eugenicists considered themselves to be a group of experts committed to identifying social problems and proposing measures of improvement. Certainly, willingness to accept it varied considerably across ethnic minorities in East-Central Europe; but amongst the German minorities, the commitment to the project of ethnic survival through eugenic and racial means was widely spread.

The argument that I am putting forward here is that while ethnic minorities were subjected to the application of eugenic theories by the state and the dominant ethnic group, at the same time they also sought to exploit eugenics for their own political purposes. During the late 1930s, especially, the Transylvanian Saxons in Romania, the Germans in Hungary and the Sudeten Germans in Czechoslovakia, embraced radical politics as the natural route to implement their own, parallel programmes of national survival and renewal. Take, for instance, the programme devised by Dr Franz Anton Basch, Chairman of the Volksbund in Hungary, in 1940:

1. German ethnic research may only be pursued by ethnically and nationally conscious researchers, who devote themselves unconditionally to the destiny of their own ethnic group. 
2. The research of the ethnic group is a definitive example of the synthesis of the loyalty to the ethnic community and the state, and it should not, under any circumstances, be inhibited or become endangered by the old traditions of the previous generations working in this field.

3. Ethnic research is devoted to and serves its own ethnic group and it should not become an end in itself; it is, therefore, in the service of the racial struggles of the ethnic group.

4. Ethnic research is, furthermore, the constant, running blood in those servicing the German nation, but it must always remember its mediator role between the two nations [the majority and the minority].

5. Ethnic research represents duty and law, at the same time, and explores all areas of the ethnic group's life, including their political and racial concerns [11].

Basch's nuanced interpretation of the relationship between ethnic minority and its host-state was played out within the broader context of the management of the population, a eugenic strategy came to dominate national politics in East-Central Europe during the 1930s and 1940s. With its roots in the combined biological and social sciences, the management of the population was designed at the same time to ensure scientific remedies to the alleged decline of population, and to provide a defensive biological strategy for the nation. Basch, again, put it eloquently: "Our motto applies as well to our politics as to our research: We do not want and do not need foreigners, and we never abandon those who belong to us!" [11]

Like the Saxon eugenicists, Basch deemed marriage and reproduction crucial to the survival of the German minority in Hungary. In a short but commanding article published in 1936 in the first issue of Volk und Heimat, the journal of the German minority in Hungary, the question "Whom Shall I Marry?" was framed within the context of a eugenic vision of a healthy nation: "No!" - the prospective spouses were warned - "Your marriage is never your business alone, but that of your family and relatives. Your choice of a spouse decides the rise or demise of your nation! [...] You don't marry for your own sake or your partner's sake, but for that of the children which should come out of your marriage". And furthermore: "Our pure blood is the most valuable property that we own. [...] Therefore whoever sins against his blood, helps pave the road to death for his nation." [12]

Otto Muntendorf, a Sudeten German population expert, voiced similar arguments in his 1937 The Death of the Nation is Imminent! His appeal to the new generations of Sudenten Germans was no less passionate: "German man! German girl! The fate of your nation lies in your hands. Your choice of wife or husband will decide the nation's future. Your responsibility is to today, because it comes upon all of us, of every family, and every child, more than ever. Be mindful of yourselves." [13]

Closely connected to the issue of reproduction and the protection of marriage was child and youth welfare. The campaign of racial regeneration by applying scientific principles to infant care was an important part of this effort. By the 1930s, both the Saxon and the Sudenten German communities mounted an intense 
lobbying effort to enlarge the jurisdiction of public health professionals, encouraging the eugenicists to produce effective guidelines, codes, and procedures relating to reproduction, family and children. Writing in the journal of the Regional German Committee for Child Protection and Youth Welfare in Bohemia in 1929, Frank Swoboda expressed this eugenic responsibility thus:

"Renaissance is here how! Progressively, over time, youth welfare has become the most significant blessing for our nation, leaving its earlier, less progressive directionality behind. As long as youth welfare is gaining pace and not only as sisterly and brotherly charity, but especially focusing on the mother and the family ideal as well, the more it makes eugenics practicable; that is to say, it promotes the health of the race and its familial strength, the unity of the family in preserving the race, without taking into account the anthropological affiliation of the individual members of the nation." [14]

Equally important, Swoboda construed the eugenics practiced by the Sudeten Germans as different as the one promoted by the Czechs. Whilst the latter were more interested in social issues, the former were concerned with racial aspects of ethnic development. As Swoboda put it:

"The eugenic question for the Czechs is to make inquiries concerning the social average of each of the individual classes, the eugenic answer for the Sudeten Germans concerns the social formulation of questions made by our mothers, wives and generations." [14]

As such Sudeten German eugenics (or German eugenics in Bohemia) had a long-established and widely respected position. And Swoboda remarked proudly on their "leadership in minority racial hygiene $[. .$.$] that titles us as the most significant$ minority in Europe" [14]. This was a view adopted by political leaders as well, and the political leader of the Sudeten Germans, Konrad Henlein, for instance, often referred to the eugenic importance of motherhood and healthy marriages in his speeches. To this effect, in 1924, the German Association for Local Historical Studies and Local Development was established in Aussig (Ústí nad Labem) whose aim was to strengthen the traditional German identity in the region, but also to articulate new responsibilities for the community's social and racial welfare. In 1927, the Saxon priest and eugenicist Alfred Csallner established the Society of Child that demonised the proliferation of one- and two-child families while supporting the growth of large families. Two years later the State Association for German Youth Welfare in the Czechoslovak Republic was created, and in 1938, the Society for Family Research and Eugenics of the Germans in the Czechoslovak Republic was established.

\section{Identity Project}

After World War I, the creation of new nation states in East-Central Europe did not eradicate (albeit not for lack of trying!) the multi-linguistic and multi-religious traditions that had been around in the region for centuries. Acknowledging the 
heuristic value of eugenic sub-cultures provides a fruitful occasion to raise questions about the nationalist epistemology at the basis of all identity projects developed in EastCentral Europe after 1900. The subject of national identity in East-Central Europe has generated an enormous literature that we cannot even summarise here. It suffices to say that this nationalist epistemology was based equally on the naturalistic heritage of the Enlightenment and the positivist postulates of the early twentieth century.

For instance, the notion that the Eastern European Jews had preserved their racial individuality in contrast to those in Western Europe was one of the defining elements of the Jewish eugenic subculture in Poland. Assimilation was articulated in the widespread language of biological determinism. The more they assimilated into the dominant culture the more the Jews were exposed to the perceived generalised degeneration characterizing the Western nations. As one of the foremost Jewish eugenicist in Poland, Zewi Parnass, explained it in his 1921 Jewish Question in the Light of Science: the "racial existence" of the Western European Jews was under threat because they usually married late in life - and when they did they often married Gentiles - they had two or even less children, not too mention their "alcoholism, venereal diseases and a large number of mental and nervous diseases" [4]. For the assimilated Jews in the West, however, "the threat of their extinction seems to be far greater" - Parnass believed. "And while in the East we already have had tools to make people aware [of the importance of eugenics] and these are our religious regulations relating to racial and social life, in the West this will not be very useful, for religion has lost much of its influence" [4]. What Parnass deemed to be the two defining elements of Jewish ethnic individuality and distinctiveness during the 1920s - religion and race - was not only the main tenets of the Polish eugenic movement but also the main tropes of the Polish (and indeed European) anti-Semitic discourse.

\section{Conclusion: Toward an Integrative Research Agenda}

Scholars of nationalism, national identity and ethnic minorities remain focused on the individual nation-state - how it was constituted, administered and attacked during the twentieth century - as the object of their research. Moreover, national historiographies continue to reproduce a national paradigm established in the nineteenth century that renders essential the relationship between ethnic minorities and majorities. In East-Central Europe the sub-cultural existence of ethnic groups is rarely acknowledged. On the national stage some of these ethnic groups - such as the Hungarians and the Germans in Transylvania - perform simultaneously as former leading political elites and current minorities. Ultimately, it does not matter too much that the physical presence of Germans in Transylvania is now almost nonexistent. What is needed, however, is to connect current research on the nation-state with other analytical frameworks. Once we reconfigure the relationship between ethnic minority and ethnic majority as subcultural, dislocations within the master narratives about the past may be treated deservedly as intrinsic features of a historical process that is as much about the reality of the nation as it is about its imagining. 
I should like to conclude by offering two final remarks: Firstly, distinctive eugenic sub-cultures had developed in East-Central Europe between 1900 and 1944. Yet their theories, reception and long-term impact continue to remain obscure to scholars. We need to take into account a multiplicity of cultural and political contexts that served the complex ideological transmission and application of eugenics. Substantial comparative research and analytical effort is necessary to address the growing historiographic interest in these topics from a comparative international perspective. Moreover, the dialectic between ethnic survival and minority rights, which characterised all minority subcultures after 1918 was reflected in a new intellectual strategy deemed to provide an antidote to the encroaching power of the nation-state.

Secondly, the eugenic agenda espoused by ethnic minorities points out to an important aspect to be considered when discussing sub-cultures as integrative forces in East-Central Europe. In promoting the vision of a healthy national community regulated by scientific norms of health and hygiene, minority eugenicists promoted more than just a scientific remedy to the decline of the population's health; it also provided a defensive biological strategy for the ethnic community. What they meant, in fact, was a complete refashioning of their relationship with the host-nation based on principles of racial homogeneity and protectionism.

A substantive comparative analysis of the emergence of eugenic sub-cultures in East-Central Europe, attentive to international synergies, national particularities and asymmetrical comparisons will place new research on individuals, ethnic, gender experiences and medico-scientific professionals at the heart of this revaluation of a truly international phenomenon.

\section{References:}

1. Turda M. In Pursuit of Greater Hungary: Eugenic Ideas of Social and Biological Improvement, 1940-1941. J Mod Hist. 2013;85:558-591.

2. Bloch E. The Heritage of Our Time. Cambridge: Polity; 1991. [1935].

3. Turda M. The Nation as Object: Race, Blood and Biopolitics in Interwar Romania. Slavic Rev. 2007;66:413-441.

4. Turda M, urednik. The History of Eugenics in East-Central Europe, 1900-1944: Texts and Commentaries. London: Bloomsbury; 2015.

5. Georgescu T. The Eugenics Fortress: The Transylvanian Saxon Experiment with 'National Renewal' in Interwar Romania. Budapest: CEU Press; u štampi 2016.

6. Bucur M. M. Eugenics and Modernization in Interwar Romania. Pittsburgh: Pittsburgh University Press; 2002.

7. Turda M. Eugenics and Nation in Early $20^{\text {th }}$ Century Hungary. Basingstoke: Palgrave Macmillan; 2014.

8. László D. Fajbiológia és sterilizálás. Korunk. 1933;8:917.

9. Turda M. Crafting a Healthy Nation: European Eugenics in European Context. U: Turda M, urednik. Crafting Humans: From Genesis to Eugenics and Beyond. Goettingen: V\&R Unipress; 2013. 109-126. 
10. Meltzl Ov. Statistik der Sächsischen Landbevölkerung in Siebenbürgen. Archiv des Vereins für Siebenbürgische Landeskunde. 1885;20:215-502.

11. Basch F. Deutsche Volksforschung in Ungarn: Entwicklung und Ziele. Deutsches Archiv für Landes-und Volksforschung. 1940;4:381-382.

12. Wen heirate ich? Volk und Heimat: Blätter für das deutsche Volk in Ungarn. 1936;1:10.

13. Muntendorf O. Deine Gattenwahl entscheidet mit über die Zukunft Deines Volkes! U: Muntendorf O. Volkstod droht! Die biologische Gefahrlage des Sudetendeutschtums in Bildern und Zahlen. Teplitz-Schönau; 1937. 94.

14. Frank SF. Eugenik und Jugendfürsorge. Jugendfürsorge. Mitteilungen der Deutschen Landeskommission für Kinderschutz und Jugendfürsorge in Böhmen und des Reichsverbandes für deutsche Jugendfürsorge in der Tschechoslowakischen Republik. 1929;13(9):356.

Submitted: 21. 10. 2015.

Reviewed: 17. 11. 2015.

Accepted: 21. 11. 2015. 